\title{
THE HISTORY OF FILM ADAPTATION IN MALAYSIA: THE LONG JOURNEY OF ITS RISE AND FALL
}

\section{(Sejarah Filem Adaptasi di Malaysia: Sebuah Perjalanan Jatuh Bangun yang Panjang)}

Wan Hasmah Wan Teh

hasmahwt@usm.my

School of Humanities, Universiti Sains Malaysia.

Published online: 3 December 2018

To cite: Wan Hasmah Wan Teh. (2018). The history of film adaptation in Malaysia: The long journey of its rise and fall. Malay Literature $31(2), 361-382$.

\begin{abstract}
Morris Beja in his book Film and Literature: An Introduction, said that since the Academy Awards was introduced in 1927 - 1928, about three quarters of the award for best film was won by film adaptations. This is proof that film adaptation is a form of art that has gained the attention of the world community and was a wellknown form of narrative in the 19th and 20th centuries in Europe. This paper takes the initiative to trace the history of film adaptations in general by focusing on such films in Malaysia. Findings of the study reveal that the history of film adaptation in Malaysia started in 1933 during the filming enterprise of Cathay Film and Malay Film in Singapore up to the setting up of Merdeka Studio in Kuala Lumpur in the 1970s and beyond. The film industry in Malaysia faced many problems including the influx of imported films from Indonesia and the commercialization factor that did not guarantee profits. However, around 2006, concerted efforts were reinforced to adapt literary works into films, through workshops and competitions organized by Malaysian government bodies such as Dewan Bahasa dan Pustaka (DBP), National Film Development Corporation (FINAS) and Radio and Television Malaysia (RTM).
\end{abstract}


Keywords: film adaptation, history, Cathay Keris, Malay Film, Merdeka Studio

\begin{abstract}
Abstrak
Morris Beja dalam bukunya Film and Literature: An Introduction, mengatakan bahawa sejak Anugerah Akademi diperkenalkan pada tahun 1927 - 1928, lebih kurang tiga per empat anugerah untuk filem terbaik telah dimenangi oleh filem adaptasi. Keadaan ini merupakan bukti bahawa filem adaptasi adalah satu bentuk seni yang telah lama mendapat perhatian masyarakat dunia dan menjadi corak naratif yang terkenal pada abad ke-19 dan ke-20 di Eropah. Makalah ini mengambil inisiatif untuk menelusuri sejarah filem adaptasi secara umum dengan memberi tumpuan kepada filem adaptasi di Malaysia. Dapatan kajian mendapati sejarah filem adaptasi di Malaysia melalui liku-liku perjalanan yang panjang bermula pada tahun 1933 sewaktu zaman perusahaan Cathay Film dan Malay Film di Singapura hingga ke Merdeka Studio di Kuala Lumpur sekitar tahun 1970an dan seterusnya. Industri filem di Malaysia berdepan dengan pelbagai masalah termasuk lambakan filem import dari Indonesia dan faktor komersialisme yang tidak menjamin keuntungan. Walau bagaimanapun sekitar tahun 2006 usaha mengadaptasi karya sastera ke filem terus diperkasakan melalui bengkel dan pertandingan anjuran badan kerajaan di Malaysia seperti Dewan Bahasa dan Pustaka (DBP), Perbadanan Kemajuan Filem Nasional Malaysia (FINAS) dan Radio dan Televisyen Malaysia (RTM).
\end{abstract}

Kata kunci: filem adaptasi, sejarah, Cathay Keris, Malay Film, Merdeka Studio

\title{
INTRODUCTION
}

Film adaptation began at the same time as the advent of films in the year 1895. The first fictional movie titled L'arroseur arrosé (The Waterer Watered, 1895) directed by Louis Lumiére was adapted from an illustrated comic book by Christophe in 1889. Two more films, The Great Train Robbery (1903) and Dream of a Rarebit Fiend (1906) directed by Edwin S. Porter, which were among the earliest American films, were also adapted from theatre and comic book materials. Most of the early film adaptations were taken from the works of famous classical authors such as William Shakespeare (1564 - 1616), George Eliot (1819 - 1880), Charles Dickens (1812 - 1870), and Thomas Hardy (1840 - 1928) from Britain and Émile Zola (1840 - 1902), 
Johann Wolfgang von Goethe (1749 - 1832), Alexander Pushkin (1799 $1837)$ and Leo Tolstoy $(1828-1910)$ from Europe.

\section{EARLY HISTORY OF FILM ADAPTATION}

In 1902, a French director, Ferdinand Zecca attempted to adapt the novel L'Assommoir (1877) by Ėmile Zola into a film entitled Les Victimes de l'alcoolisme with a running time of 5 minutes (Baguley, 1992, p. 106). The length of a story in a novel precludes it from being shown in its entirety on screen. Therefore the approach used is to take only the core of the story, which is already known to the public and present this within the restricted time limit. The earliest narrative films were rarely more than three to five minutes in length, which were gradually extended to 20 minutes in 1910 , reaching up to the the standard length of 90 to 120 minutes by the end of the era of silent movies.

Nevertheless, there were efforts to incorporate an entire story into one film. One such film was Erich von Stroheim's Greed in 1924, based on Frank Norris' novel Mc Teague (1899). This film was 16 hours long but it was later cut down to 8 hours and finally reduced to 2 hours 20 minutes.

As a matter of fact, the limited length of time afforded by films did not deter efforts to adapt novels into films. D.W. Griffith directed a film about the struggles during the American Civil War (1861 - 1865), titled The Birth of a Nation which was released on 8 February 1915 and its running time was only 1 hour 30 minutes. This film is considered an important milestone because of its technical innovations as well as its narrative style and treatment of the controversial issue of white dominance and the Ku Klux Klan. The Birth of a Nation was an adaptation from a bestselling novel and drama by Thomas E. Dixon called The Clansman. This film while portraying white supremacy also showed the negative side of the white people and the positive side of the black community, thus generating numerous feedback from various parties. Some came from politicians, film enthusiasts, and scholars. D.W. Griffith responded to these feedback by making another film called Intolerance in the following year (David, 2004, p. 74). It was meant to highlight the dangerous consequences of intolerance to human civilization.

Apart from that, a famous filmmaker, David Lean succeeded in making epic films such as The Bridge on the River Kwai (1957), a film adaptation from the novel by a French author, Pierre Boulle, Lawrence of Arabia (1962), adapted from an autobiography of T.E. Lawrence when he was in Arabia during the first world war. Another film, Doctor Zhivago (1965) was 
adapted from the novel by Boris Pasternak, a famous Russian poet and writer who won the Nobel Prize for Literature in 1958. Next, Ryan's Daughter (1970) was a loose adaptation from the novel Madame Bovary by Gustave Flaubert, a well-known French writer and A Passage to India (1984), a film adaptation from the novel by E. M. Forster, an English novelist.

David Lean proved that film adaptation could elevate a director's ranking. For instance, all five film adaptations mentioned were hugely successful everytime the films were shown to the public and won many awards in prestigious events such as the Academy Awards, Golden Globe Awards, BAFTA and others. Doctor Zhivago for instance is a novel filled with controversy. It is a love story set during the Depression following the Russian Revolution and Civil War that caused the decline of Russia from about 1917 till 1921. It is also a critique of the Soviet system for sacrificing culture and humanism in pursuing their leaders' ideology. Although this novel is 592 pages long, it did not discourage David Lean from transforming it into a film that runs for 3 hours and 17 minutes. He was able to weave a plot of progress and decline against a backdrop of human relationships and political intrigues with a gripping wartime background. Interesting pre-war and post-war scenes that were brought to life in this film were repeatedly used in documentary films (Glenn Andreiev, May 2010).

Considered a masterpiece, this film shows how he had progressed at adapting novels into films compared to his previous efforts and at the same time succeeded in displaying intertextual interaction to convey the sexual and political themes of the novel. Reaping the rewards for his efforts, the film that he directed won five Oscars at the Academy awards, for Best Art Director, Best Cinematography, Best Costume Design, Best Music and Best Screenplay. At the Golden Globes, the film won five awards, for Best Motion Picture, Best Actor (Omar Sharif), Best Director, Best Original Score and Best Screenplay. David was able to prove that it was not impossible to adapt novels into films, even a difficult one like Doctor Zhivago with its dominant political theme and Russia as its backdrop.

Morris Beja in his book Film and Literature: An Introduction, stated that since the Academy Awards was introduced in 1927 - 1928, about three quarters of the awards for best film were won by film adaptations (Beja, 1979, p. 78). Thus, film adaptation became a popular narrative style in the 19th and 20th centuries in Europe. This is proof that film adaptation is not a newly explored art but has long gained the attention of the world community. One of the most recent is the film directed by Danny Boyle 
Slumdog Millionaire (2008) which was adapted from the novel $Q \& A$ by Vikas Swarup, an Indian writer and diplomat. It tells the story of an uneducated orphan who works as a waiter and takes part in the "Who Will Win a Billion?" contest for the sole purpose of liberating a young prostitute by the name of Nita. This film shook the film world when it won eight Oscars at the Academy Awards in 2009, five awards at the Critics Choice Awards, four at the Golden Globes and seven at BAFTA. Indirectly, due to these achievements, directors became extremely motivated to continue adapting novels into films.

The success of these films was also an acknowledgment of the novelist and his work. For instance, W. Somerset Maugham, a well-known English author managed to attract many directors to film a number of his novels. Furthermore, his novels were filmed repeatedly by several directors, among them The Painted Veil directed by Richard Boleslawski in 1934, and remade by John Curran in 2006. The Razor's Edge was filmed in 1946 by the director Edmund Goulding and later by John Byrum in 1984.

Jane Austen's Pride and Prejudice (1813) is another example of a novel filmed repeatedly by several directors. Robert Z. Leonard filmed the novel in 1940, Andrew Black in 2003, Gurinder Chadha who inserted Bollywood elements and modified the title to Bride and Prejudice in 2004, finally Joe Wright in 2005. Each of her six novels has been adapted for the silver screen. Sense and Sensibility was filmed by Ang Lee in 1995 and Persuasion by Roger Michell in 1995, a film adaptation which is regarded as the most successful of its kind.

J. K. Rowling, an author of children's novels, is famous for the seven series of a magical fantasy adventure, titled Harry Potter. All seven of the series have been bought by Warner Brothers to be adapted for the silver screen, shattering box office record at each showing. This outstanding success catapulted J. K. Rowling's name and the novels have become the all-time best selling novels in history and have been translated into 65 languages. As example, the first publication for her fourth book Harry Potter and Goblet of Fire reached 38 million copies in the United States and 13 million copies for the whole country (Anatol, 2003, p. x). Due to Warner Brothers' purchase of Harry Porter's copyright, the novel began to attract its own following. This is clearly a case of an adaptation process that changed the life of an unknown writer into that of a celebrity, who was listed by the Sunday Times Rich List in 2008 as one of the richest women in Great Britain. 
The huge successes achieved by filmmakers and novelists in the West have inspired adaptation efforts in Asian countries. These countries' capacity to adapt literary works, especially novels into films is undeniable and the creative results they produced have also gained recognition at the international level.

\section{THE HISTORY OF MALAYSIA'S FILM ADAPTATION: HOW IT BEGAN IN SINGAPORE}

The history of films in Malaysia (previously called The Malay States) began with the screening of a documentary news film titled Diamond Anniversary Celebration of Queen Victoria in 1898 by the British colonialists. In 1907, for the first time the Malay States witnessed the building of a cinema in Alhambra, Singapore by an Englishman, Willis. In 1929, the film, The Jazz Singer (USA, 1927) was the first talking movie that was screened at Victorian Concert Hall, Singapore (Hassan and Wong, 2002, p. 301).

1933 was a significant year in the country's film history when the Motilal chemical Company produced the first Malaysian film called Laila Majnun, a love story taken from tales of the Middle East and was directed by B.S. Rajhans from India. The cast was recruited from the Bangsawan group because they had the talent and experience in acting. This film is said to be of high quality as much of the filming was done in India which at that time was known for having the equipment and know-how for filmmaking. The response to Laila Majnun was encouraging, especially among the Malays. There were a number of reasons for this: the film was in the Malay language and it had been able to penetrate the English, Chinese and Indian markets as well. In addition, the film was adapted from a tale popularly known to the society as a national folklore and was frequently dramatized by bangsawan groups (Hamzah, 2004, p. 11).

The success of Laila Majnun caught the interest of two entrepreneur brothers from Shanghai known as Shaw Brothers. They began to produce four films circa 1938 by replicating stories from Chinese films to be directed by directors imported from Shanghai. The four films were Mutiara, Ibu Tiri, Bermadu and Tiga Kekasih. According to Hassan and Wong, all four films failed to attract the local audience as there was a preponderance of foreign elements in the films. The audience could not comprehend the themes of these films as they were alien to Malay culture and psyche (Hassan and Wong, 2002, p. 302). 
As a result, two film production companies, the Malay Film Productions (MFP) and Cathay Keris Film Productions in the Malay States had to act fast by borrowing Indian themes and stories which were already known to the public, and directors from India were engaged by these companies (Salleh, 1989, pp. 2 - 5). The directors took popular stories and translated them into English. These were then retranslated into Malay by local writers, after which they were presented with excessive entertainment such as songs from beginning to end as shown in all the Indian movies. But these were the kind of films that mesmerized the Malay audience not only because of the entertainment factor but they also portrayed shared cultural values (Paul F. Agusta, 14 May, 2004).

Malaya, from 1933 till 1938 was still in the early stage of its filmmaking history. These slow, initial steps petered off during the first world war in 1941 and stopped completely during the Japanese Occupation since the Shaw Studio in Singapore was taken over by the military and placed under Eiga Haikya Sha. Malaya was then deprived not only of their own films but the Hollywood and British films were also banned completely. According to Hatta Azad Khan, during the three years of Japanese Occupation in Malaya, that is from 1942 - 1945, not even one Malay film was produced in Singapore and Indonesia, (1997, p. 66).

To fill this vacuum, Japan brought in their own films which were filled with propaganda that portrayed Japan as a good and great nation, in their desire to promote the creation of a Greater East Asia (Hamzah, 2004, p. 15). In addition, they produced two propaganda films March to Singapura and Marat No Tora by bringing in actors and workers from Japan and locals were used as extras together with British war prisoners (Hatta, 1997, p. 66).

Filmmaking continued after the end of the war around 1945 with the film Seruan Merdeka (1946) directed by B. S. Rajhans and produced by Malayan Art Productions, i.e. the first film production company set up after the Second World War (Salleh Ghani, 1989, p. 2). It is clear from this brief review on of the beginning of films in the Malay States, that the adaptation process in Malaya began as early as 1933 with the film Laila Majnun. Shaw Brothers' films around the year 1938 were merely replicas of Chinese films made in Shanghai. What Cathay Keris Productions, Malay Film Productions and Shaw Brothers did later was to engage directors from India, such as B. S. Rajhans, L. Krishnan, Phani Majumdar, Dhiresh Ghosh, S. Ramanathan, B. N. Rao, K. R. S. Sastry and Kiedar Sharma who became pioneers of the 
film-making industry in Malaya by borrowing films from India and adapting them to suit local taste.

Local taste in the Malay states from 1933 to 1970 veered towards stories that were already well known such as legends, myths, the Malacca sultanate, fables and folklore which the society had heard of, orally or through written material. For instance, Hang Tuah (1956) directed by Phani Majumdar, narrates the story of a great Malay warrior who is loyal to the king to the extent that he would kill his own friend who rebelled. This story resonates with the Malay psyche and has a high level of egocentrism. Hence, this film which idolizes the hero was remade several times from 1956 till 2004, according to the director's perspective in interpreting the hero. Additionally, there were films like Hang Jebat (1961) directed by Hussein Hanif, Tun Teja (1961) by L. Krishnan, Si Tanggang (1961) by Jamil Sulong, Tun Fatimah (1962) by Salleh Ghani, Mahsuri (1959) by B. N. Rao, Raja Laksamana Bentan (1959) by Jamil Sulong, Raja Bersiong (1963) by Ramon Estella, Puteri Gunong Ledang (1961) by S. Romai Noor, Sultan Mahmud Mangkat di Julang (1961) by K. M. Basker and many more.

Films adapted from myths were also popular with the audience, among them Batu Belah Batu Bertangkup (1959) directed by Jamil Sulong, Badang (1962) by S. Romai Noor, Sri Mersing (1961) by Salleh Ghani, Singapura dilanggar Todak (1961) by Omar Rojik, and Bawang Putih Bawang Merah (1959) by S. Romai Noor. These stories were filmed not only because they were already known to the public but there was also a market demand for didactic elements to be inserted as lessons to be learnt. According to $\mathrm{Ku}$ Seman $\mathrm{Ku}$ Hussein, a local film observer, although the adaptations were undertaken because of market demands, these efforts reveal the early signs of how a piece of work could be perceived from different angles.

All the myths, fables and legends carry similar themes, namely justice, a king's majesty, failure in love, forced marriage due to pressure, abuse by stepmother, differences in status and loyalty to the king. The dearth of themes in Malay films at that time was because filmmakers were reluctant to use novels as their source, apart from other factors like financial constraints and inabilty to buy over the rights of a novel. Novel writing in the Malay states had actually begun in 1925, eight years earlier than the film which was adapted from a novel, Hikayat Faridah Hanum (also known as Hikayat Setia Asyik Kepada Maksyuknya) by Syed Sheikh Al-Hadi. The novel is full of the life and culture of the Malay society. 
Cathay Keris Productions finally realized the uniqueness of Malay novels after Ho Ah Loke produced the film Cinta Gadis Rimba, directed by Datuk L Krishnan in 1958. This film used a novel by Harun Aminurrashid as its source with S. Romai Noor and M. Amin as the actors. Directed by L. Krishnan, it is among nine films produced by Cathay Keris under Ho Ah Loke and six of them garnered huge gross profits (Hamzah, 2004, p.53). The interesting love story plus some erotic elements were the main factors for filming this novel. A love story would always appeal to the audience. This particular love story involves a young Malay man and an Iban girl whose beliefs and cultures differ from each other, and there was also the erotic portrayal of Iban women who are typically barechested. This film was also marketed overseas with the title The Virgin of Borneo but it did not connect with the locals or the overseas audience.

In 1963, M. Amin made a film entitled Rumah Itu Dunia Aku, which was adapted from a novel by Hamzah Hussein. This film is about the life of a child abused by her stepmother in their own house. To ensure the success of this film, M. Amin collaborated with Hamzah Hussein who was then given the task of writing the screenplay and dialogue. Rumah itu Duniaku is said to have followed closely the story in the novel by Hamzah Hussein, although the Film Censor Board in Johor Bahru made several cuts (Hamzah, 2004, p. 64). Cathay Keris paid Hamzah Hussein five thousand ringgit as the author and for the copyright of the novel and 1500 ringgit for writing the screenplay. (Hamzah, 2004, p. 65). The purchase of copyright and payment for screenplay to novelists should encourage more literary writers to offer their work for film adaptations.

However, the process of film adaptation from novels again faced a stumbling block after Rumah Itu Dunia Aku was filmed, from about 1963 till 1969. As is publicly known, there was stiff competition between two film production companies, namely Malay Film Productions and Cathay Keris Film Productions in producing Malay movies. Added to this was the advent of television around 1961 in Singapore which greatly reduced the number of moviegoers. The public's wavering interest led the two companies to look for new strategies to bring back the Malay audience. One of the strategies was to look for new themes that would be a change from the previous films, such as myths from other countries. Cathay Keris Productions for instance attempted the filming of a Greek myth, Oediopus and named it Kalong Kenangan (1964), directed by Hussein Haniff. For the filmmakers, this mythical story was unique and would be able to shock the 
audience (Hamzah, 2004, p. 63). Instead, this theme of incestual marriage between a mother and son received a lukewarm response. Cathay Keris did not give up when seven years later in 1971, another film was produced using the same theme, directed by M Amin. Even the title was coined for its shock value, so that the audience would be curious about the storyline. Again, this film adaptation, Jahanam, which used the same Greek mythical story, did not receive an encouraging response (Hamzah, 2004, p. 64).

The efforts at diversifying themes and stories led too many films in the Malay states becoming the product of replicating or as it is sometimes called, plagiarism of foreign films that had broken box office records (Hamzah, 2004, p. 88). Shaw Brothers upheld this formula, as they believed that it could gross big profits. The same is voiced by Jamil Sulong as follows:

Why stories are not taken from novels is because the publishers are foreigners and do not have a feel for the contents, therefore directors are not tasked with making stories out of novels. In fact, normally a story is copied from a foreign film with a theme that the producer likes, or it already has achieved box office status.

(Jamil, 1982, pp. $147-148$ )

However, not all these projections are accurate, as the Cathay Keris film mentioned above proved. The formula of replicating will only dampen the creative process of local talents, the results of which will be a big departure from the culture of the local society.

\section{THE HISTORY OF MALAYSIA'S FILM ADAPTATION: HOW IT BEGAN IN KUALA LUMPUR}

The process of film adaptation stalled once again because the film production companies in Singapore faced many problems, among them workers' strikes which were launched by the Singapore amalgamated Trade Union until both production companies had to shut down their studios in the middle of the 1960s (Hamzah, 2004, p. 114). At the same time, Merdeka Studio Productions was set up in Kuala Lumpur in early 1960 by Mr. Ho Ah Loke (Salleh, 1989, p. 5). Many directors, workers and actors began to move to Kuala Lumpur for a new start, including Datuk L. Krishnan, Salleh Ghani, P. Ramlee, Diresh Gosh, Jamil Sulong, S. Kadarisman, Omar Rojik, 
M. Amin, Nas Achnas, Jins Shamsuddin and Sudarmadji. The first film produced by Merdeka Studio was Tun Teja (1961) directed by L. Krishnan who still adapted stories from legends included in Hikayat Hang Tuah and Sulalatus Salatin.

Nevertheless, film adaptations reappeared in 1969 when the film Bukan Salah Ibu Mengandung directed by Jins Shamsuddin was released. This film was adapted from a novel Memang Nasib Celaka Badan by Harun Hassan who also wrote the screenplay. This is the first film directed by Jins Shamsuddin after his return from further studies at the London School of Film Techniques. He is also credited as a pioneer of the era of educated young Malays in the film world and clearly, the knowledge he brought back benefitted Merdeka Film Productions (HassanHassan and Wong, p. 309). Jins Shamsuddin also directed the film Bukit Kepong (1981). This film was adapted from a novel by Ismail Johari about a brave struggle by a group of policemen and local residents fighting off a communist attack at Bukit Kepong, Johor in 1950. At the 3rd Malaysian Film Festival in 1982, Jins Shamsuddin's talent as a director was recognized when he won the Award for Best Director for Bukit Kepong, which won the Best Film Award and Special Jury Award for adaptation of a historical event.

In the same year, 1969, Merdeka Film also released Kalau Berpaut di Dahan Rapuh adapted from a novel by Alias Ali and directed by Omar Rojik. The theme of failure in love was the main reason the novel was filmed, whereby the female protagonist sought revenge by breaking the hearts of the men in her life. In the mid 1970s, Merdeka Film stopped producing Malay films. The excuse was that the response towards Malay films had declined and did not bring in profit for the production company, compared to the Malay films which were produced in Singapore. At the end of the 60 s and early 70 s there was an influx of Indonesian films in Malaysia. These films were presented in colour and wider screen (Hatta, 1997, p. 170). The decline of the studio system (Shaw Brothers era) and the dearth of local filmmakers of Malay movies drove film distributors to import Indonesian films.

Indonesian films seemed to have the potential to replace Malay films as the language used was almost similar, the actors were also from the same ethnic groups sharing the same culture through its themes and characters (Hatta, 1997, p. 111). The handsome actors and beautiful actresses in Indonesian films were a source of attraction to the local audience who were already bored with Malay films that cast the same actors, some of whom were 
neither well known nor talented. Apart from that, the early Indonesian films that were brought into Malaysia offered strong storylines and characters, and the cast that were selected were suitable for the characters they played, thus the acting seemed natural (Hatta, 1997, p. 111). All these contributed to the popularity of Indonesian films in Malaysia after Malay films became scarce.

However, at the end of the 70s, Indonesian films began to lose their appeal as the audience's interest shifted to Malay films produced by Bumiputera companies. For example, Sabah Films produced Keluarga Comat (1975), directed by Aziz Satar, Perusahaan Filem Malaysia (PERFIMA) produced Menanti Hari Esok (1977) directed by Jins Shamsuddin, Fleet Communications Sdn. Bhd produced Abang directed by Rahim Razali (1981), Angkatan Seniman Abad XXX's produced Abang 2 (1993), Anak Sarawak (1989), and Rentak Desa (1990) all directed by Rahim Razali. There were several film activists too, such as Tan Sri Kamarul Ariffin, Rosnani Jamil and Hussin Abu Hassan who involved their families in the film industry (Hamzah, 2004, pp. 117 - 123). The change in Malaysian audience's interest was because at the end of the ' 70 s, Indonesian films started producing films with sexual elements, which the public feared would influence the younger set (Salleh, 1989, pp. $6-7$ ).

With the emergence of Bumiputera film companies, the process of adaptation flourished again, though not at the same rate as in other countries and it did not stagnate at the same level. The desire to vary themes in films made producers turn their attention to novels. For instance, in 1982, Syed Kechik Film Productions produced a film directed by Shahrom Mohd Dom, called Langit Petang, which was adapted from a novel by A. Samad Said. This novel revolves around the characters of Hafiz who wants to break free from the cocoon of normal life and is influenced by an individual by the name of Pak Arif, a forgottten fighter for Independence and Zakiah, a lady of the night who hates men and uses them. Somehow, the film which was directed by Shahrom Mohd Dom, shows a vastly different interpretation of the source novel. The director's act of portraying a new situation that is different from the original novel by omitting and replacing some signs, symbols and important events upset the novelist (Wahab, 1992, p. 6). However, A. Samad Said later felt vindicated when Johan Jaafar directed a six episode television drama, Langit Petang Dua Belas Tahun Kemudian in 1991. Wahab stated that in presenting new characters, plot and interpretation, Johan still kept the spirit and essence of the text, to the author's satisfaction $(1992$, p. 6). 
In 1993, Jamil Sulong continued to make film adaptations with the film Ranjau Sepanjang Jalan which was adapted from a well-known novel by Shahnon Ahmad. The story of Lahuma's family, Jeha's craziness after Lahuma's death, the struggles of Sanah and her six younger sisters who eked out who a living from the padi fields was the theme carried into the film. However, many were disappointed with the film, including the author himself. They felt that Jamil Sulong followed the narrative of the novel too closely, so that its possibilities as a film were ignored (1992, p. 9). Wahab acknowledges the film's achievement in its visuals, but was disappointed with its storytelling (1992, p.8). This could be due to a misconception about adaptation and the feeling that the director as the person responsible for the film should not make any amendments.

It was a different case eleven years later, when Rithy Panh, a director from Cambodia made a film adaptation from the same novel. Rithy Panh was attracted to the theme about life in Ranjau Sepanjang Jalan and adapted it into a film entitled Rice People in 1994. Although Cambodia is another country and geographically different, it shares almost a similar culture and lifestyle with the Malays in Malaysia. This film was a contender for the Palme d'Or Award at the Cannes Film Festival in 1994. In addition, Rice People was also screened in North America for the Toronto International Film Festival and nominated for Best Foreign Language Film at the 67th Academy Awards, thus making it the first Cambodian film to be part of the prestiguous Award. Looking at the number of competitions it was in, clearly Rice People that based its idea from a Malaysian novel was able to make a mark for its country at the international level.

\section{THE HISTORY OF FILM ADAPTATION IN MALAYSIA FROM THE 1990S UNTIL 2000 AND BEYOND}

In 1990, Khadijah Hashim's novel Mira Edora was adapted into a film of the same name, directed by Zulkefli M. Osman. A story about love, a broken home and psychology, it was brought to life in the film starring some of the country's great actors such as Julia Rais, Noor Kumalasari, Mustapha Kamal, Rahim Maarof, Accapan and Ruminah Sidek. The film made use of the commercial value of the actors to portray the characters. It is during this era that many film productions in Malaysia engaged actresses who are of mixed blood like Julia Rais, Ramona Rahman, Deanna Yusoff and Sofia Jane. Another strategy to attract audiences to the cinema was getting popular singers like Rahim Maarof, Jamal Abdillah, M. Nasir and Awie to 
act in these films. All these were strategies used to attract the viewers to patronise cinemas.

In 1997, U-Wei Shaari directed a film called Jogho, which was adapted from a novel Juara (1976) written by S. Othman Kelantan (1976). This novel provides a window into Malay politics at the Malaysia-Thailand border by presenting its main protagonist as being disillusioned with the world of politics and changes direction by participating in bull fights. This adaptation by U-Wei was not appreciated by the local audience but did attract the attention of other countries when it was invited to be shown at the International Film Festival in Singapore (1998), Pusan (1998), Cinemanila (1999) and Nantes (2001).

Khalid Salleh as the lead actor in the film made Malaysia proud with his acting talent when he won the Best Actor Award at the 43rd Asia Pacific Film Festival in 1998, in Taipei. In Malaysia, Jogho was the Jury's choice at the 14th Malaysan Film Festival in 1999 for Best Actor, Best Film, Best Director, Best Screenplay Awards as well as for the Best Poster category

U-Wei who is well known for his controversial works represents the 5th group of the Malaysian Cinema Voices by Hassan Muthalib. The Malay psyche is his favourite theme and he likes to explore the negative aspects of the Malay race. The fifth group is part of the revolution in filmmaking which slowly emerged in the $1980 \mathrm{~s}$. The directors in this group are those who are educated about films, have theatre background or knowledge about films as a form of expression (Hassan, 2005). They include Rahim Razali, Nasir Jani, Mansor Puteh, Anuar Nor Arai, Adman Salleh, Mahadi J. Murat, Shuhaimi Baba, U-Wei Haji Shaari, Erma Fatima, Hishamuddin Rais, Teck Tan and Yasmin Ahmad.

Jogho was not the first film directed by U-Wei that caught international attention. Previously, U-Wei adapted a short story, Barn Burning (1939), written by William Faulkner. The title of the film was changed to Kaki Bakar and made into a television series in 1995. For some reason, the film was rejected for screening and was only released in October 2001, six years after its completion. The film tells a story of a wanderer from Java, Indonesia who attempts to inculcate Javanese traditional values in his son, Kesuma. Class differences in society oppress him and drives him to violence and this leaves a huge impact on his son. Kaki Bakar is a very close adaptation of the original source although some modifications were made to suit Malaysian society's background and culture. 
In terms of achievement, this particular film that was directed by U-Wei is the first Malaysian film to be screened at the Cannes Film Festival in France in 1995 and is considered a real discovery by Richard Corliss, a Time Magazine critic. At the 1st South-East Asian Biennial Film Festival in Phnom Penh it received the Special Jury Award in 1997 and was invited to take part in 20 Film Festivals including in Berlin and Montreal. It also won the award for Best Film (foreign film category) at the 17th Brussels International Independent Film Festival in 1995 in Belgium.

Film adaptations can be based on many sources, namely novels, comics, short stories, poetry, songs, true stories, articles and many others. Another adaptation directed by U-Wei, Buai Laju-Laju, screened in 2004, is proof of this. A high calibre director who is full of creative ideas, U-Wei was inspired by a film, The Postman Always Rings Twice, which was adapted from James M. Cain's novel. He has not stopped exploring literary works as potential sources for filmmaking. Joseph Conrad's novel, entitled Almayer's Folly is the source of adaptation for U-Wei's latest film entitled Hanyut (2016). This novel looks at the Malay world from an extraordinary angle through the eyes of a Dutch trader who was stranded in this world for years in order to pursue his ambiguous dreams. It was a case of European arrogance brought down by the tricks of the natives, causing the trader, Almayer, to lose everything, even his daughter, Nina.

It must also be mentioned here that the process of adaptation in Malaysia has not always been focussed on the novel as there were attempts to make films from comics. One such film is Mat Som, directed by Hatta Azad Khan, based on a comic of the same name, which is the work of Mohammad Nor Khalid (Datuk) or more well known as Lat. The film Mat Som (1992) was the first film directed by Hatta who also wrote the script, earning him the award for Best Screeplay at the 9th Malaysian Film Festival. Hatta admitted that the audience who came to watch Mat Som were those who had read the comic and they were fans who followed all of Lat's comics which were published in Berita Minggu and the New Straits Times (Norashikin, April 2009). The comic Mat Som inspired Hatta to bring to life its characters in his film and it was screened at International Film Festivals in Tokyo, Fukuoka, Hawaii, Bangalore, Taipei and Jakarta.

In 2004, Rosnani Jamil directed a film, Bicara Hati adapted from a novel, Pelangi Pagi by Khadijah Hashim. It is about a 17-year old girl who falls in love with her teacher and tries to win his heart by working very hard until she is able to enter university. According to FINAS statistics available 
on their website, this story of unrequited love managed to yield RM100 000 only and failed to draw the crowds. But a new actress (Fazura) who played the lead character succeeded in winning the Award for Best New Actress at the 17th Malaysian Film Festival in 2004. Rosnani Jamil revealed that there were discussions between the novelist and script writer in the early stages regarding changes that were to be made. She acknowledged that there were no problems in adapting the novel because Khadijah Hashim gave the script writer the freedom to recreate and visualise the novel in her own way. This made it easier for the director and scriptwriter to do their work.

In 2004, the most expensive film was made in Malaysia. It was produced by Infiniti Production at a total cost of RM20.5 million, including the cost of production and promotion. The film, Puteri Gunung Ledang which was directed by Saw Teong Hin, is an adaptation from the story of Hang Tuah, a Malay warrior who was famous for his agility, wisdom and loyalty to the Malay kings and as the hero in the myth of Puteri Gunung Ledang. The stories of these heroes are found in several Malay literary works such as Sulalat al-Salatin, Hikayat Hang Tuah and the text, Sulalat Al-Salatin: Sejarah Melayu. A film with the same name was produced by Cathay Keris Film in 1961, directed by S. Roomai Noor. It was aimed at criticising Sultan Mahmud Syah who used his troops and his kingdom's resources to achieve his own ends.

However, this adaptation directed by Saw Teong Hin is a departure from the story known to the public. The script writer took the Malaccan Malay Sultanate as the background, while the warrior Hang Tuah, Puteri Gunung Ledang and several other figures were deployed to depict a story that is different from the original legend. The glaring discrepancy is the love story between Hang Tuah and Puteri Gunung Ledang, who is the sister of Gusti Adipati from the kingdom of Majapahit. Puteri Gunung Ledang won 5 awards including Best Director (Saw Teong Hin), Best Screenplay (Mamat Khalid), Best Music Score and Best Art Direction at the Malaysian Film Festival, 2005 and the Special Jury Award for Innovative and Inspiring Film. It also participated in the 61st Venice International Film Festival in 2004 and a year later in the 48th San Francisco International Film Festival.

Further on, in 2010 Malaysia saw a film directed by Sharad Sharan titled Lagenda Budak Setan, adapted from a famous novel Ahadiat Akashah. In the mid 1990s, this novel was frequently talked about by local novel enthusiasts and is still discussed until today. This popular novel, story, which is about a man, called "budak setan", and his strong feelings of love, 
managed to reap RM4.28 million in 2010, according to FINAS' website. This film that was produced by Astro Shaw with Tarantella Pictures also won the Best Original Story Award, which was given to Ahadiat Akashah as the novelist and the Best Actress Award to Lisa Surihani at the 23rd Malaysia Film Festival.

\section{ADAPTATION OF NOVELS INTO FILMS AND ITS PROBLEMS}

In the process of adapting novels into films, there will always be some divergence between the book and the film. Mira Edora is one such example.

In 1990, the novel Mira Edora was chosen by Take One Production Company to be adapted into a film, under the direction of Zulkeflie M. Osman. The Producer, Sharif Haji Sabari, chose this particular novel as it was a bestseller at the time. The Production team discussed with the novelist, Khadijah Hashim, regarding their intention to film the novel and she was asked to write the script. However, after viewing the first script that she wrote, they found that they had to make changes.

According to Zulkeflie, the first draft written by Khadijah deviated significantly from the proper format of a film script (interview with Zulkeflie M. Osman on 23 November 2010). Khadijah is a novelist and much of her imaginative vision could not be incorporated into the film script. Finally, the Production team decided that the script be rewritten by Zulkeflie based on the first draft 136, penned by Khadijah Hashim. The second draft was the product of discussions between the novelist and the scriptwriter, whereas the third draft was entirely the work of the scriptwriter. The third draft was the final script which was agreed upon for filming. Based on the interview with Zulkeflie, he said that when the Production team obtained consent from the author to buy its copyright, they had the right to make whatever changes that were deemed necessary to depict the story in a film. Whether to change the plot, scenes or leave out certain events.

Although the characters and scenes underwent modifications, nonetheless the film was still classified as a faithful adaptation of the novel. All characters and scenes that were modified, added or left out in the film still retained the characteristics inherent in the novel. No character or scene impaired the original intent of the novel although the film did not retain all episodes found in the novel. Zulkeflie tried his utmost to transfer the whole content of the novel into the film but did not focus on the emotions of the characters which in fact would have reinforced the theme of the story. Khadijah Hashim 
expressed her dissatisfaction with the presentation because the screenplay writer, the director and producer did not consult her as had been agreed upon before filming (Hizairi, 2000, p. 84). Further, she added she was only invited to the preview of the film after everything had been completed. Khadijah was not happy with the changes in dialogue from the novel as she felt that it was just doing the same thing all over again. If the dialogues had to be changed, it was sufficient to just shorten or condense the dialogues and not altered entirely (Hizairi, 2000, p. 84).

The novelist is of the opinion that in adapting novels, it is important that the author and scriptwriter hold discussions in order to have a better understanding of the whole story. Personally, the author feels that the novel Mira Edora is finer than the film version. This view is different from that expressed by the director and the scriptwriter. Zulkeflie said that the adaptation made was not from the novel itself. He rewrote the script based on the first script written by Khadijah Hashim. If there were changes, they were not based on his ideas but the author's. All the changes done on the first, second and third drafts were still under Khadijah Hashim's supervision, although there were conflicts or disagreement on several matters. The Production team acknowledged that they could not envision what each and every reader of the novel imagines or perceives. In this context, Khadijah too would have her own vision of the novel. Finally, the Production team decided to visualize the story according to the script they had prepared based on the first draft by Khadijah and Zulkeflie was chosen to be the scriptwriter.

The film Mira Edora in the end did not do as well as expected. It managed to gross around RM400,000 only whereas the cost of production was around RM600,000. Zulkeflie stated that during this era many films were not well-received and Mira Edora was one of them although they had included commercial elements, a formula which was utilized by every film produced during that time. Mira Edora was one of the films that made use of commercial values which were the trend at the end of 1989 and early 1990. As Gaik Cheng explained:

The 1990's younger filmmakers attempt to break down the binary of art versus commercial cinema, but only for pragmatic reasons of survival in the industry. For example, in order to attract moviegoers and music fans, Shuhaimi Baba employs singers in her films "Selubung" and "Layar Lara", Mahadi J. Murat features the handsome but bland Azhar Sulaiman in "Sayang Salmah", and the leading roles go to beautiful actors like Deanna Yusoff, Ramona Rahman, Tiara 
Jacquelina and Sofea Jane Hisham, all four of whose pan-Asia looks might presumably attract non-Malay viewers as well .

(Gaik Cheng, 2006, pp. $100-101$ ).

Similarly, Zulkefli also tried to attract audiences to view the film Mira Edora by engaging actresses like Julia Rais, who was a popular star at that time with her Pan-Asian looks (which was also a requirement of the novel) as a means to attract non-Malay viewers. Rahim Maarof and his his songs were also selected because of his popularity as a singer at that time and would have been able to attract the singer's fans. These were the marketing strategies devised before filming started (interview with Zulkeflie M. Osman on 23 November 2010). Zulkeflie did voice his opinion that a film adaptation should be faithful to its source, and that the director and scriptwriter should follow closely the novel it is adapting. Firstly, the filmmaker should adhere to the original story and not leave out important events that reinforce the story. Secondly, the characters in the novel should be intact, the lead as well as the supporting ones. He believes that the originality of the story should go hand in hand with the creative visuals.

\section{INITIATIVES AND ENCOURAGEMENT BY VARIOUS GOVERNMENT AGENCIES}

The Malaysian government in fact has been fully supportive of the efforts at adaptation being carried out from time to time. Many workshops and seminars have been conducted to create interest and increase efforts to adapt literary works into films. For example, Dewan Bahasa dan Pustaka (DBP) and the National Film Development Corporation Malaysia (FINAS) organised a "Script Writing for Adaptation of Literary Work into Film Workshop" to train scriptwriters on the methods and techniques of writing script for adaptation, to increase a writer's understanding and quality of scriptwriting for adaptation and screenplay as well as to encourage the publication of works for adaptation. Apart from that, DBP in collaboration with RTM took the initiative to adapt novels and short stories published by DBP into television dramas, starting from the year 2006. Among them are Mufarakah written by Rahman Shaari, Hujan Sudah Teduh by Zaharah Nawawi, Senjakala by Baharuddin Kahar, Saudagar Besar dari Kuala 
Lumpur by Keris Mas, Jaringan by Rosmini Saari and a short story entitled Cahaya pada Jiwa written by Faisal Tehrani.

In addition, DBP together with FINAS and FDAM (Film Directors Association Malaysia) organized a Script Writing Competition for Film Adaptation from Novels. Five novels were selected based on the value and interesting subject matter that would be suitable for cinematic adaptation and if the novel had previously won in a novel writing contest. The novels were Sandera (Arenawati), Interlok (Abdullah Hussein), Empangan (Zakaria Ali), Pemberontakan (Chian Jong Lai) and Bedar Sukma Bisu (Faisal Tehrani). They stood to win big prizes: RM15,000 for the first place, RM8,000 for second place and RM5,000 for third place.

FINAS also promised to find a production company to film the winning script. The winner would not only win a big sum of money but would be paid based on the copyright and royalties from the producer (Feride, 3 Ogos 2011). On top of that, a really good and creative script would be brought to the international level by the organisers. The objective of this competition is to bring huge benefits to both mediums, literature and films, as a means of recognition for a novel and to help local films turn out good and interesting stories.

\section{CONCLUSION}

Novels have proven to be good source material for cinematic adaptation and have been the main choice of many film directors since 1902. The tradition of adapting novels into films created a reciprocative relationship that has profited both sides. Many directors have become famous due to the success of their film adaptations and many novelists have become well known after their novels were adapted into films. Film adaptation is not impossible to realise but it is a genre that has its own following. Malaysia began adapting novels into films in 1958 with the novel Chinta Gadis Rimba, followed by Rumah Itu Dunia Aku in 1963, Memang Nasib Celaka Badan and Kalau Berpaut di Dahan Rapuh, both in 1969. After a period of thirteen years, Malaysia came up with film adaptations of the novels, Langit Petang by A. Samad Said in 1982 and Ranjau Sepanjang Jalan by Shahnon Ahmad in 1983. Broadly speaking, there were long gaps in the production of film adaptations between the years 1958, 1963, 1969, 1982, 1983, 1990, 1997, 2004 and 2010. In fact, the history of novel writing began way back in 1925 with the novels Hikayat Faridah Hanum, Kawan Benar followed by novels loaded with big issues like Salina by A Samad Said, 
Tivi by Shahnon Ahmad, Perempuan Politikus Melayu by Faisal Tehrani, and many more. It is therefore imperative that government programmes like script writing workshops organized by DBP, FINAS and RTM continue in order to encourage adaptation of literary works into films and TV dramas.

\section{REFERENCES}

Anatol, Gissele Liza. (2003). Reading Harry Potter: Critical essays. Westport: London.

Andreiev, Glenn. Doctor Zhivago. (n.d.).

(http://www.filmsinreview.com/2010/05/06/doctor-zhivago/) Accessed on 3 December 2010.

A. Wahab Hamzah. (September 1992). Novel ke Filem: Hubungan Yang Mencurigakan? Dewan Sastera 6 - 9.

Baguley, David. (1992). Emile Zola: L'Assommoir. Cambridge University Press: Cambridge.

Beja, Morris. (1979). Film and literature: An introduction. Longman Inc: New York. Cook, David A. (2004). A history of narrative film. 4th edition. Norton \& Company: New York.

Feride Hikmet Atak. (2011). Pertandingan Skrip Filem Adaptasi Tawar Hadiah RM15,000. MStarOnline. (http://mstar.com.my/hiburan/cerita. asp?file $=\% 2 \mathrm{~F} 2011 \% 2 \mathrm{~F} 8 \% 2 \mathrm{~F} 3 \% 2 \mathrm{Fmstar}$ hibu ran $\% 2 \mathrm{~F} 20110802153120 \& \mathrm{sec}$ = mstar_hiburan) Accessed on 30 October 2011.

Gaik Cheng, Khoo. (2006). Reclaiming adat: Contemporary Malaysia film and literature. UBC Press: Canada.

Hizairi Othman. (2000). "Adaptasi novel ke filem: Analisis perbandingan antara filem Melayu dan filem Barat." M.A. dissertation (1999/2000), Department of Media and Communication Studies, Faculty of Arts and Social Sciences, University of Malaya (Unpublished dissertation).

Hamzah Hussein. (2004). Memoir Hamzah Hussin: Dari Keris Film ke Studio Merdeka. 2nd print. Penerbit Universiti Kebanggaan Malaysia: Bangi.

Hassan Muthalib and Wong Tuck Cheong. (2002). Gentle winds of change. In ArunaVasudev, Latika Padgaonkar and Rashmi Doraiswamy (Eds.) Being and becoming: The cinemas of Asia. Macmillan: India. (pp, $301-328)$.

Hatta Azad Khan. (1997). The Malay cinema. Bangi: UKM Publishers.

Interview with Zulkeflie M. Osman, film director of "Langit Petang" (1982) on 23 November 2010 at KFC restaurant, Damansara, Selangor.

Jamil Sulong. (1982). Filem Melayu setengah abad (1933 - 1982). Universiti Sains Malaysia: Pulang Pinang.

Paul F. Agusta. (2004). Early Malaysian films emerge as savory multicultural "Rojak". The Jakarta Post. (www.p-ramlee.com/press/jakartapost05142004. txt) Accessed on 7 September 2008. 
MALAY LITERATURE VOLUME 31 NUMBER 2 DECEMBER 2018

Norashikin Ahmad Nor. Filem yang boleh mewakili negara-bangsanya dalam semua aspek." (t.th) (www.sinemamalaysia.my/main/article/filem_yang boleh_mewakili_negarabangsanya_dalam_semua_aspek_2130) Accessed on 23 December 2009

Salleh Ghani. (1989). Sejarah filem Melayu. Art Printing: Kuala Lumpur.

Received: 7 June 2018

Accepted: 3 October 2018 